DOI: https://doi.org/10.32689/2523-4536/61-10

УДК 338

Шевченко I. Б.

кандидат економічних наук, доцент,

Національний технічний університет України «Київський політехнічний інститут імені Ігоря Сікорського»

Шендерівська Л. П.

кандидат економічних наук, доцент,

Національний технічний університет України «Київський політехнічний інститут імені Ігоря Сікорського»

Shevchenko Inna

Candidate of Economic Sciences, Associate Professor,

National Technical University of Ukraine

"Igor Sikorsky Kyiv Polytechnic Institute"

Shenderivska Lina

Candidate of Economic Sciences, Associate Professor,

National Technical University of Ukraine

"Igor Sikorsky Kyiv Polytechnic Institute"

\title{
ЕКСПЕРИМЕНТАЛЬНА БАЛАНСОВА МОДЕЛЬ ДЛЯ ДІАГНОСТИКИ КРИЗОВОГО СТАНУ ПІДПРИЕМСТВ ВИДАВНИЧО-ПОЛІГРАФІЧНОЇ ГАЛУЗІ
}

\section{EXPERIMENTAL BALANCE MODEL FOR DIAGNOSTICS OF THE CRISIS STATE OF ENTERPRISES PUBLISHING AND PRINTING INDUSTRY}

\begin{abstract}
Сучасна економічна система України перебуває у досить нестабільному положенні. Цьому сприяють як міжннародні політичні, економічні та фінансові кризи, світова пандемія 2020 року, так $і$ внутрішня політична й економічна ситуація. Для багатьох вітчизняних підприємств, особливо у видавничо-поліграфічній галузі, постала реальна загроза банкрутства. Менеджменту комериійних організацій необхідно мати ефективний інструмент для ранньої діагностики кризових явищ, можливості виявити їх причину та усунути ї̈ шляхом коригування власних стратегій розвитку. У статті досліджено фінансово-економічний стан видавничих та поліграфічних підприємств, виявлено фактори, щзо мають найбільший вплив на їх фінансову стійкість, та розроблено балансову модель діагностики кризового стану. В ході подальшого дослідження та вдосконалення моделі вона може стати надійним засобом швидкого виявлення потенційних загроз фінансовому та економічному стану підприємства.
\end{abstract}

Ключові слова: видавничо-поліграфічна галузь, кризовий стан, фінансова стійкість, балансова модель діагностики кризового стану, відносні показники фінансового стану підприємства.

The modern economic system of Ukraine is in a rather unstable position. In modern conditions, the deterioration of the economic situation is becoming increasingly important crisis management of the enterprise, namely the choice of optimal methods for diagnosing the crisis of enterprises. Based on the work of experienced scientists in crisis management, we can say that to diagnose the crisis of the enterprise must first determine the nature of the crisis and based on the life cycle of the enterprise, it is necessary to assess the potential threat of bankruptcy of the publishing industry to identify the crisis and exit from it through corporate strategies of recovery and restructuring As a result of constant changes in legislation, political and economic life of the state, there are many fundamentally new factors influencing domestic enterprises of the publishing and printing industry. This is facilitated by international political, economic and financial crises, the global pandemic of 2020, and the domestic political and economic situation. For many domestic enterprises, especially in the publishing and printing industry, there is a real threat of bankruptcy. The management of commercial organizations needs to have an effective tool for early diagnosis of crisis phenomena, the ability to identify their cause and eliminate it by adjusting their own development strategies. The article examines the financial and economic condition of 6 publishing and printing companies, identifies the factors that have the greatest impact on their financial stability and developed a balance model for crisis diagnosis. To diagnose the crisis of publishing and printing companies use the same methods, only taking into account some features of the industry described earlier. And the key to the successful elimination of most crises, the company should identify them in advance and take a number of appropriate preventive measures. It is necessary to use a proactive method that allows you to either eliminate the cause of the crisis, or adapt the company to new conditions and thus avoid a crisis. We propose to use the method of correlation-regression analysis - is the construction and analysis of economic- 
mathematical model in the form of a regression equation (correlation equation), which expresses the dependence of the resultant feature on one or more feature factors and estimates the degree of connection density. With further research and improvement of the model, it can become a reliable means of rapid identification of potential threats to the financial and economic condition of the enterprise. The experience of studying the methodology of construction of such a model will be useful for future professionals to apply it in future professional activities.

Keywords: publishing and printing industry, crisis state, financial stability, balance model of crisis diagnostics, relative indicators of financial condition of the enterprise.

Постановка проблеми. В сучасних умовах погіршення економічного становища все більшого значення набуває антикризове управління підприємством, а саме вибір оптимальних методів діагностики кризового стану підприємств. Внаслідок постійних змін у законодавстві, політичному та економічному житті держави виникає досить багато принципово нових факторів впливу на вітчизняні підприємства видавничо-поліграфічної галузі. Як зазначається у схваленій Урядом Концепції популяризації вітчизняної видавничої продукції на 2014-2018 роки [2, с. 3], «системна криза охопила видавничу справу, $<$... $>$ книга в Україні втратила свою провідну роль, внаслідок чого відбувається стрімке зниження рівня освіченості, культури, духовності суспільства, що призводить до втрати наукового, інтелектуального потенціалу країни». Саме тому проблема антикризового управління стає, як ніколи, актуальною в умовах сьогодення.

Аналіз останніх досліджень і публікацій. Наукові дослідження щодо пояснення виникнення та перебігу кризових явищ у функціонуванні та розвитку соціально-економічних систем різних економічних рівнів проводились у класичних роботах представників світової наукової думки, таких як Дж.М. Кейнс, М.Д. Кондратьєв, К. Маркс, М.I. Туган-Барановський, И. Шумпетер, У. Бівер, Г. Спрінгейт, П. Самуельсон, а також у працях сучасних вітчизняних та іноземних учених, таких як М.П. Афанасьєв, А.С. Бажутін, І.О. Бланк, А.І. Дмитренко, В.А. Гросул, І.Ю. Спіфанова, Н.О. Іванов, О.В. Коваленко, Л.О. Лігоненко, I.О. Макаренко, О.І. Пушкар, Л.С. Ситник. Теоретична й методологічна проблематика формування інституційних механізмів антикризового управління отримала відображення в працях таких зарубіжних учених, як Е. Альтман, А. Бетнорі, А.П. Градов, Л.Е. Грайнер, Т.В. Іванова, П.В. Круш, Р. Тафлер, Е.О. Уткін.

Проблеми формування механізмів діагностики виникнення та розгортання кризових явищ в Україні розкрито в роботах вітчизняних науковців, таких як М.Д. Білик, I.О. Бланк, О.О. Терещенко, Т.С. Унковська, Н.M. Ушакова.

Відзначаючи фундаментальний характер теоретико-методологічних надбань та при- кладних розробок розв'язання задачі з формування концепції антикризового управління на підприємстві, враховуючи ускладнення внутрішньої його побудови та не завжди передбачуваний під час ретроспективного аналізу деструктивний вплив факторів зовнішнього середовища, вважаємо, що слід переосмислити наявні підходи, їх аналіз та синтез, а також дослідити нові концептуальні засади 3 формування антикризової політики.

Спираючись на праці досвідчених учених у питаннях антикризового управління, можемо сказати, що для діагностики кризового стану підприємства перш за все необхідно визначити характер наявної кризи, а з огляду на життєвий цикл розвиток підприємства потрібно здійснити оцінювання потенційної загрози банкрутства підприємства видавничо-поліграфічної галузі для виявлення стадії кризи і виходу з неї через корпоративні стратегії відновлення і реструктуризації [3].

Мета статті полягає в аналізі фінансовоекономічного стану шести видавничих та поліграфічних підприємств за 2019-2020 роки, виявленні факторів, що найбільше впливають на результативний показник роботи підприємства, та створенні кореляційно-регресійної моделі діагностики кризового стану.

Виклад основного матеріалу. Проаналізувавши особливості видавничо-поліграфічних підприємств, можемо визначити поліграфічну промисловість як галузь матеріального виробництва, що характеризується цільовим характером, наявністю специфічних засобів виробництва, особливостями друкованої продукції, взаємодією виробника і покупця через низку виробничих і посередницьких ланок [1].

Ранне визначення слабких сигналів про наближення загрози кризи можливе під час організації безперервної діагностики зовнішнього та внутрішнього середовища підприємства.

Пропонуємо розглянути послідовність кроків діагностики щодо прийняття антикризових рішень на умовному поліграфічному підприємстві за слабким сигналом кризового характеру.

Перший крок - аналіз та оцінювання зовнішніх економічних явищ на рівні макросередовища для визначення загальних тенденцій розвитку економіки та поліграфії; динаміки кількості поліграфічних підпри- 
ємств та обсягу друкованої продукції загалом по країні; зміни платоспроможності населення; динаміки обсягу друкованої продукції за окремими асортиментними групами; потреби та реального використання новітніх технологій [4].

Другий крок - аналіз та оцінювання зовнішніх економічних явищ на рівні навколишнього бізнес-оточення, таких як поточний рівень конкуренції; конкурентні переваги підприємств, які працюють на ринку; інформація про нового конкурента (мета створення, базова технологія, перелік та характеристика основного устаткування, орієнтовний асортимент продукції, фінансові ресурси, взаємозв'язок з місцевими органами влади, команда менеджерів) [4].

Третій крок - визначення, аналіз та оцінювання можливих внутрішніх проміжних економічних явищ, що є наслідками слабких сигналів кризового характеру, у розрізі таких функціональних галузей внутрішнього середовища підприємства:

- виробництво (скорочення обсягу виробництва, недовикористання виробничих потужностей, поява понадлімітних залишків матеріалів і сировини, зниження продуктивності праці, збільшення простоїв обладнання);

- маркетинг (втрата частки ринку, зменшення кількості споживачів продукції, збільшення витрат на збут тощо);

- організація управління;

- фінанси (зменшення доходів (прибутку) від основної діяльності (у нашому випадку - виготовлення друкованої продукціï), зниження показників рентабельності, зростання залишків готової продукції, збільшення тривалості обігу капіталу, величини кредиторської та дебіторської заборгованості, нераціональна зміна структури активів, дефіцит власних оборотних коштів);

- трудові ресурси (виникнення вимушених простоїв і неритмічна робота, збільшення плинності кадрів, зниження рівня заробітної плати та порушення термінів іiі виплати, погіршення соціально-психологічного клімату в трудовому колективі);

- технологія (збільшення витрат на систематичне оновлення технології та придбання новітніх зразків поліграфічного обладнання) [4].

Четвертий крок - прийняття таких антикризових рішень відповідно до ступеня визначеної загрози:

- перегляд умов роботи зі споживачами продукції, підписання довгострокових договорів;

- зміна цінової стратегії та розроблення системи знижок для постійних клієнтів;
- налагодження тісних ділових відносин 3 потенційними споживачами або споживачами, які співпрацюють 3 конкурентами;

- розширення географічних кордонів господарської діяльності; аналіз постачальників сировини та матеріалів щодо надійності і цінової стратегії, пошук альтернативних шляхів постачання;

- аналіз витрат на виготовлення окремих видів продукції задля їх зниження без зміни якісних параметрів;

- аналіз можливостей виробництва та виходу на ринок з новими видами продукції;

- оптимізація товарних запасів і запасів сировини й матеріалів;

- перегляд кількості, складу та кваліфікаційного рівня персоналу підприємства;

- встановлення додаткового контролю за обсягом та своєчасністю погашення дебіторської та кредиторської заборгованостей;

- активізація маркетингової діяльності;

- перегляд стратегічних цілей і тактичних планів [4].

Загалом можна сказати, що для діагностики кризового стану видавничо-поліграфічних підприємств застосовують такі ж методи, тільки з урахуванням деяких особливостей галузі, що описані раніше, а запорукою для успішної ліквідації більшості кризових явищ підприємству $\epsilon$ їх завчасна ідентифікація, а також вжиття низки відповідних превентивних заходів.

Необхідним є використання проактивного методу, який дає змогу або завчасно ліквідувати причину виникнення кризового явища, або адаптувати підприємство до нових умов, отже, уникнути кризового стану.

Пропонуємо використати метод кореляційно-регресійного аналізу, що $є$ побудовою та аналізом економіко-математичної моделі у вигляді рівняння регресії (рівняння кореляційного зв'язку), що виражає залежність результативної ознаки від однієї або кількох ознак-факторів, а також оцінює ступінь щільності зв'язку.

Правильне застосування кореляційних методів дає змогу зрозуміти глибинну сутність процесів взаємозв'язків. Кореляційні зв'язки виявляються не в кожному окремому випадку, а в середньому для багатьох випадків.

Таким чином, за зібраними даними по шести підприємствах видавничо-поліграфічної галузі за 2019 і 2020 роки (табл. 1, 2), яких представляють показники-індикатори кризи на підприємстві, будуємо математичну модель залежності випадкової величини Ү від випадкових величин $\mathrm{X}_{1}, \mathrm{X}_{2}, \mathrm{X}_{\mathrm{n}}$.

Побудову та оцінювання якості економікоматематичної (економетричної) моделі необхідно здійснювати в такій послідовності. 
1) Побудувати кореляційну матрицю для даних величин і оцінити статистичну значущість кореляції між ними.

2) 3 огляду на наявність між ендогенною змінною і екзогенними змінними лінійної залежності оцінити параметри регресійної моделі за методом найменших квадратів. Обчислити вектори регресійних значень ендогенної змінної та випадкових відхилень.

3) Побудувати багатофакторну модель.

4) Узагальнити результати оцінювання параметрів моделі та результати перевірки моделі на адекватність.
Далі, спираючись на судження експертів, ми визначили, що найбільш тісний зв'язок спостерігається між такими показниками:

- рентабельність власного капіталу;

- коефіцієнт мобільності;

- коефіцієнт інвестування;

- коефіцієнт оборотності майна;

- коефіцієнт оборотності запасів.

Для побудови моделі множинної регресії ми складаємо зведену таблицю (табл. 3) вищезазначених показників по шести підприємствах видавничо-поліграфічної галузі за два періоди, яка представлена нижче.

Таблиця 1

Вихідні дані для аналізу по підприсмствах за 2019 рік

\begin{tabular}{|c|c|c|c|c|c|c|}
\hline \multirow[b]{2}{*}{ Показник } & П1 & $\Pi 2$ & П3 & $\Pi 4$ & П5 & $\Pi 6$ \\
\hline & $\begin{array}{l}2019 \\
\text { рік }\end{array}$ & $\begin{array}{c}2019 \\
\text { piк }\end{array}$ & $\begin{array}{c}2019 \\
\text { рiк }\end{array}$ & $\begin{array}{c}2019 \\
\text { рiк }\end{array}$ & $\begin{array}{c}2019 \\
\text { рік }\end{array}$ & $\begin{array}{c}2019 \\
\text { рік }\end{array}$ \\
\hline Коефіцієнт поточної ліквідності & 1,38 & 1,52 & 1,13 & 0,71 & 6,63 & 1,03 \\
\hline Коефіцієнт швидкої ліквідності & 0,943 & 0,92 & 0,89 & 0,61 & 1,2 & 1,02 \\
\hline Коефіцієнт абсолютної ліквідності & 0,074 & 0,4 & 1,1 & 0,45 & 0,18 & 0,55 \\
\hline Коефіцієнт мобільності & 0,35 & 0,9 & 0,69 & 0,12 & 0,92 & 1,73 \\
\hline Коефіцієнт інвестування & 0,64 & 0,94 & 0,62 & 0,33 & 0 & 1,05 \\
\hline Коефіцієнт оборотності майна & 1,304 & 2,13 & 2,38 & 2,65 & 0,53 & 3,09 \\
\hline Коефіцієнт о & 7,171 & 2,2 & 3,66 & 1,85 & 1 & 4,88 \\
\hline Коефіцієнт оборотності запасів & 15,729 & 4,49 & 5,8 & 12,6 & 3,46 & 303,16 \\
\hline Коефіцієнт оборотності дебіторс & 13,659 & 4,06 & 3,59 & 9,92 & 6,82 & 10,84 \\
\hline Коефіцієнт оборотності кредиторської заборгованості & 2,487 & 2,06 & 5,68 & 13,16 & 4,16 & 4,45 \\
\hline Рентабельність витрат (прод.) & 9,69 & $-5,65$ & 45,9 & 6,72 & 6,36 & 13,26 \\
\hline Рентабельність чистого доходу від реалізації & 8,83 & 5,3 & 18,9 & 6,67 & 4,76 & 0,04 \\
\hline Рентабельність власного капіталу & 1,85 & 0,68 & 9,6 & 0,61 & 0,027 & 14,63 \\
\hline Рентабельність активів & 0,87 & 0,55 & 1,33 & 2,22 & 0,023 & 5,65 \\
\hline Рентабельність оборотних активів & 4,87 & 2,26 & 3,03 & 1,95 & 0,3 & 8,93 \\
\hline
\end{tabular}

Джерело: авторська розробка

Таблиця 2

Вихідні дані для аналізу по підприємствах за 2020 рік

\begin{tabular}{|c|c|c|c|c|c|c|}
\hline \multirow[b]{2}{*}{ Показник } & П1 & $\Pi 2$ & $\Pi \mathbf{3}$ & $\Pi 4$ & П5 & П6 \\
\hline & $\begin{array}{c}2020 \\
\text { piк }\end{array}$ & $\begin{array}{c}2020 \\
\text { piк }\end{array}$ & $\begin{array}{c}2020 \\
\text { piк }\end{array}$ & $\begin{array}{c}2020 \\
\text { рік }\end{array}$ & $\begin{array}{c}2020 \\
\text { pik }\end{array}$ & $\begin{array}{l}2020 \\
\text { рік }\end{array}$ \\
\hline Коефіцієнт поточної ліквідності & 1,069 & 1,29 & 0,3 & 0,14 & 6,64 & 1,14 \\
\hline Коефіцієнт швидкої ліквідності & 0,518 & 0,69 & 0,26 & 0,62 & 1,08 & 1,1 \\
\hline Коефіцієнт абсолютної ліквідності & 0 & 0,56 & 0,94 & 0,31 & 0,11 & 0,62 \\
\hline Коефіцієнт мобільності & 0,49 & 0,72 & 0,78 & 0,48 & 0,92 & 1,37 \\
\hline Коефіцієнт інвестування & 0,62 & 0,5 & 0,68 & 0,45 & 0 & 1,16 \\
\hline Коефіцієнт оборотності майна & 1,744 & 2,52 & 2,27 & 1,18 & 0,45 & 5,26 \\
\hline Коефіцієнт оборотності мобільних коштів & 7,515 & 2,68 & 3,39 & 1,44 & 1 & 9,11 \\
\hline Коефіцієнт оборотності запасів & 13,348 & 4,92 & 5,9 & 4,93 & 3,69 & 252,75 \\
\hline Коефіціє & 15,438 & 6,23 & 4,12 & 7,37 & 6,15 & 21,54 \\
\hline Коефіцієнт оборотності кредитс & 3,001 & 1,85 & 3,79 & 12,36 & 3,24 & 9,43 \\
\hline Рентабельність витрат (прод.) & 11,24 & $-4,27$ & 48.3 & 8,59 & 5.62 & 9.66 \\
\hline Рентабельність чистого доходу від реалізації & 10,11 & 9,48 & 12,3 & 5,95 & 3,98 & 0,03 \\
\hline Рентабельність власного капіталу & $-2,64$ & 1,53 & 10,3 & 0,64 & 0,002 & 15,85 \\
\hline Рентабельність активів & $-1,27$ & $-1,12$ & 2,29 & 2,36 & 0,002 & 7,79 \\
\hline Рентабельність оборотних активів & $-5,97$ & $-4,51$ & 3,45 & 1,84 & 0,18 & 13,5 \\
\hline
\end{tabular}

Джерело: авторська розробка 
Вихідні дані для побудови моделі множинної регресії

\begin{tabular}{|c|c|c|c|c|c|}
\hline $\begin{array}{c}\text { Підприємство/ } \\
\text { період }\end{array}$ & \begin{tabular}{|c|}
$Y$ \\
(рентабельність \\
власного \\
капіталу)
\end{tabular} & $\begin{array}{c}\mathbf{X}_{1} \\
\text { (коефiщicнт } \\
\text { мобільності) }\end{array}$ & $\begin{array}{c}\mathbf{X}_{2} \\
\text { (коефіщіснт } \\
\text { інвестування) }\end{array}$ & $\begin{array}{c}X_{3} \\
\text { (коефіціснт } \\
\text { оборотності } \\
\text { майна) }\end{array}$ & $\begin{array}{c}\mathrm{X}_{4} \\
\text { (коефіцієнт } \\
\text { оборотності } \\
\text { запасів) }\end{array}$ \\
\hline П1/2019 & 1,85 & 0,35 & 0,64 & 1,304 & 15,729 \\
\hline П2/2019 & 0,68 & 0,9 & 0,94 & 2,13 & 4,49 \\
\hline П3/2019 & 9,6 & 0,69 & 0,62 & 2,38 & 5,8 \\
\hline П4/2019 & 0,61 & 0,12 & 0,33 & 2,65 & 12,6 \\
\hline П5/2019 & 0,027 & 0,92 & 0,19 & 0,53 & 3,46 \\
\hline П6/2019 & 14,63 & 1,73 & 1,05 & 3,09 & 303,16 \\
\hline П1/2020 & 2,64 & 0,49 & 0,62 & 1,744 & 13,348 \\
\hline П2/2020 & 1,53 & 0,72 & 0,5 & 2,52 & 4,92 \\
\hline П3/2020 & 10,3 & 0,78 & 0,68 & 2,27 & 5,9 \\
\hline$\Pi 4 / 2020$ & 0,64 & 0,48 & 0,45 & 1,18 & 4,93 \\
\hline П5/2020 & 0,002 & 0,92 & 0,23 & 0,45 & 3,69 \\
\hline П6/2020 & 15,85 & 1,37 & 1,16 & 5,26 & 252,75 \\
\hline
\end{tabular}

Джерело: авторська розробка

Дослідимо ступінь кореляційної залежності між змінними. Для цього побудуємо кореляційну матрицю, використовуючи

Кореляційна матриця залежності

Таблиця 4 між змінними

\begin{tabular}{|c|c|c|c|c|c|}
\hline & $\mathbf{Y}$ & $\mathbf{X}_{\mathbf{1}}$ & $\mathbf{X}_{\mathbf{2}}$ & $\mathbf{X}_{\mathbf{3}}$ & $\mathbf{X}_{\mathbf{4}}$ \\
\hline $\mathbf{Y}$ & $\mathbf{1}$ & & & & \\
\hline $\mathbf{X}_{\mathbf{1}}$ & 0,6832 & $\mathbf{1}$ & & & \\
\hline $\mathbf{X}_{\mathbf{2}}$ & 0,7578 & 0,6001 & $\mathbf{1}$ & & \\
\hline $\mathbf{X}_{\mathbf{3}}$ & 0,7704 & 0,4282 & 0,7763 & $\mathbf{1}$ & \\
\hline $\mathbf{X}_{\mathbf{4}}$ & 0,8001 & 0,8069 & 0,7303 & 0,7054 & $\mathbf{1}$ \\
\hline
\end{tabular}

засоби «Аналізу даних» в Microsoft Excel. Кореляційна матриця наведена в табл. 4.

3 кореляційної матриці бачимо, що на рентабельність власного капіталу впливають всі чотири регресанти, тобто коефіцієнт мобільності, коефіцієнт інвестування, коефіцієнт оборотності майна і коефіцієнт оборотності запасів мають сильний кореляційний зв'язок з рентабельністю власного капіталу.

Так само можемо відзначити наявність кореляційної залежності між пояснювальними (екзогенними) змінними, що може свідчити про наявність у моделі явища мультиколінеарності. Побудуємо багатофакторну

Вплив факторів на результативні показники

Таблиця 5

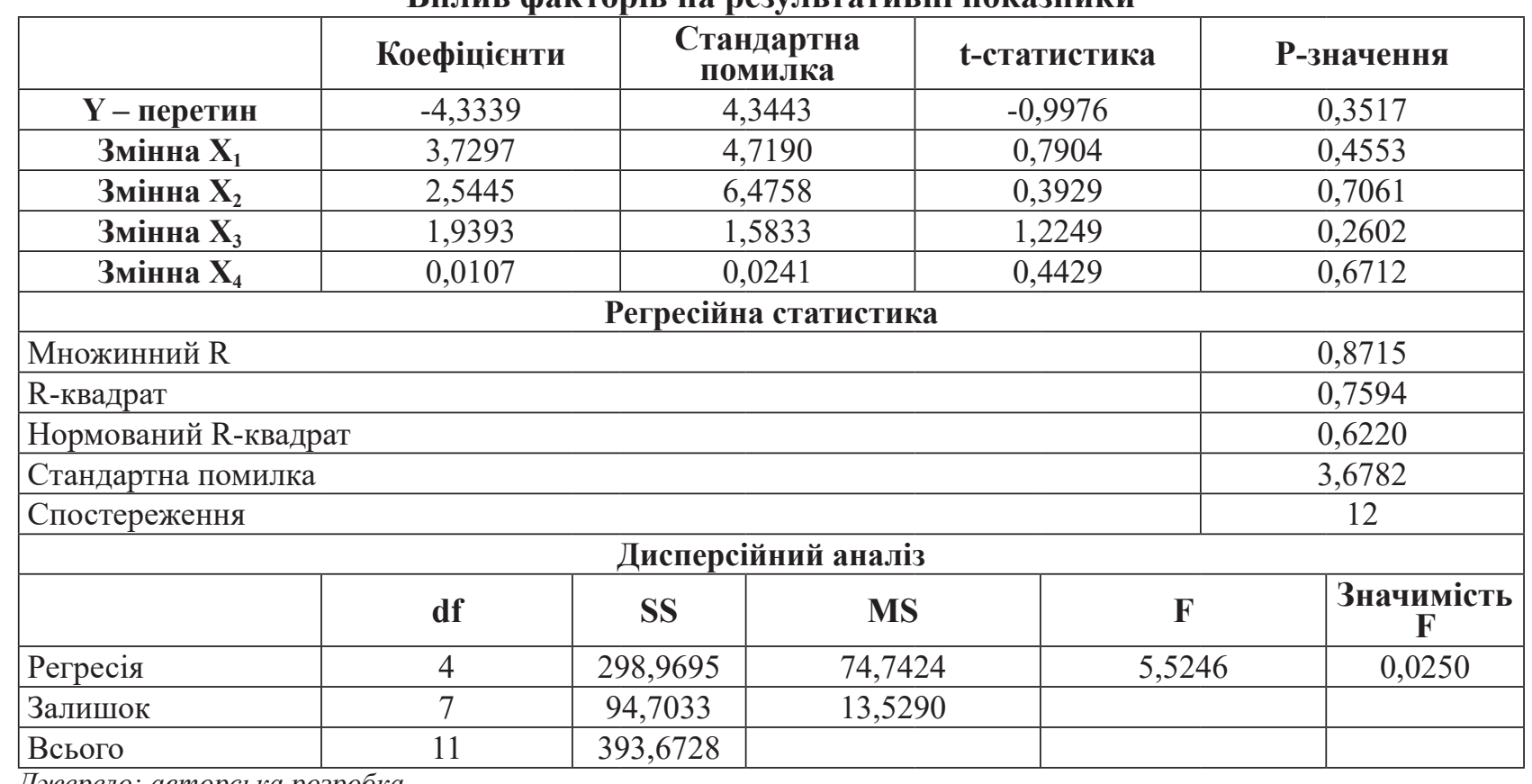

Джерело: авторська розробка 
регресійну модель, у якій залежна змінна Y - рентабельність власного капіталу.

Визначимо коефіцієнти рівняння регресії: $\mathrm{Y}=\mathrm{b}_{0}+\mathrm{b}_{1} \times \mathrm{X}_{1}+\mathrm{b}_{2} \times \mathrm{X}_{2}+\mathrm{b}_{3} \times \mathrm{X}_{3}+\mathrm{b}_{4} \times \mathrm{X}_{4}$.

Результати розрахунку множинної регресії в чисельному вигляді подані у табл. 5 .

Як випливає з даних, отриманих за допомогою Excel методом найменших квадратів, отримана багатофакторна модель матиме такий вигляд:

$$
\begin{gathered}
\mathbf{Y}=-4,3339+3,7297 \times \mathbf{X}_{\mathbf{1}}+2,5445 \times \\
\times \mathbf{X}_{\mathbf{2}}+1,9393 \times \mathbf{X}_{\mathbf{3}}+0,0107 \times \mathbf{X}_{\mathbf{4}},
\end{gathered}
$$

де $\mathrm{X}_{1}$ - коефіцієнт мобільності; $\mathrm{X}_{2}$ - коефіцієнт інвестування; $X_{3}$ - коефіцієнт оборотності майна; $\mathrm{X}_{4}$ - коефіцієнт оборотності запасів.

Отримане рівняння виражає залежність рентабельності власного капіталу (Y) від коефіцієнта мобільності $\left(\mathrm{X}_{1}\right)$, коефіцієнта інвес- тування $\left(\mathrm{X}_{2}\right)$, коефіцієнта оборотності майна $\left(\mathrm{X}_{3}\right)$ і коефіцієнта оборотності запасів $\left(\mathrm{X}_{4}\right)$.

Коефіцієнти рівняння показують кількісний вплив кожного фактору на результативний показник за незмінності інших.

Висновки. Побудоване рівняння (модель) регресії, хоча й адекватне з експериментальними даними для підприємств видавничополіграфічної галузі, проте для використання в практичних цілях потребує подальшого доопрацювання, оскільки воно має такі недоліки, як автокореляція залишків випадкових відхилень, мультиколінеарність.

Названі недоліки можуть привести до ненадійності оцінок, тому необхідно накопичувати інформаційну базу даних показників фінансового стану підприємств видавничо-поліграфічної галузі та провадити подальші наукові дослідження для вдосконалення моделі.

\section{Список використаних джерел:}

1. Должанський А.М. Організаційно-технологічні особливості поліграфічного виробництва та їх вплив на побудову обліку витрат виробництва. Торгівля, комериія, підприємництво : збірник наукових праць Львівської комерційної академії. 2000. С. 64-66.

2. Концепція популяризації вітчизняної видавничої продукції та читання на 2014-2018 роки. Вісник Книжкової палати. 2013. № 4.

3. Кочетков В.М., Волошаненко Є.В. Виявлення загрози банкрутства підприємств видавничо-поліграфічної галузі на основі дискримінантних моделей. Економічний вісник Донбасу. 2014. № 1. С. 74-78. URL: http://www.evd-journal.org/download/2014/2014-1/11.pdf (дата звернення: 26.01.2021).

4. Штангрет А.М. Окремі аспекти використання проактивного антикризового управління на поліграфічних підприємствах. Наукові записки Української академї̈ друкарства. 2007. № 1. С. 98-103. URL: http://nz.uad.lviv.ua/static/media/1-11/16.pdf (дата звернення: 26.01.2021).

\section{References:}

1. Dolzhansjkyj A.M. (2000) Orghanizacijno-tekhnologhichni osoblyvosti polighrafichnogho vyrobnyctva ta jikh vplyv na pobudovu obliku vytrat vyrobnyctva [Organizational and technological features of the printing industry and their impact on construction cost accounting production]. Torghivlja, komercija, pidpryjemnyctvo: zbirnyk naukovykh pracj Ljvivsjkoji komercijnoji akademiji, pp. 64-66.

2. Koncepcija populjaryzaciji vitchyznjanoji vydavnychoji produkciji ta chytannja na 2014-2018 roky (2013) [The concept of popularization of domestic publishing products and reading for 2014-2018]. Visnyk Knyzhkovoji palaty, no. 4.

3. Kochetkov V.M., Voloshanenko Je.V. (2014) Vyjavlennja zaghrozy bankrutstva pidpryjemstv vydavnycho-polighrafichnoji ghaluzi na osnovi dyskryminantnykh modelej [Identifying the threat of bankruptcy of publishing and printing companies on the basis of discriminant models]. Ekonomichnyj visnyk Donbasu, no. 1, pp. 74-78. Available at: http://www.evd-journal.org/download/2014/2014-1/11.pdf (accessed 26 January 2021).

4. Shtanghret A.M. (2007) Okremi aspekty vykorystannja proaktyvnogho antykryzovogho upravlinnja na polighrafichnykh pidpryjemstvakh [Some aspects of the use of proactive crisis management in printing companies]. Naukovi zapysky Ukrajinsjkoj akademijy drukarstva, no. 1, pp. 98-103. Available at: http://nz.uad.lviv.ua/ static/media/1-11/16.pdf (accessed 26 January 2021). 